\title{
STUDYING THE STRUCTURAL AND OPTICAL PROPERTIES OF ZNO NANOPARTICLES PREPARED BY SONOCHEMICAL METHOD
}

\author{
M. Ashoush ${ }^{1}$, Asmaa. Abdelghany ${ }^{4}$, S.N. Elsayed ${ }^{2}$, L. M. Alsaba ${ }^{3 *}$, A. Eid ${ }^{4}$. \\ (1) Faculty of Science, Al-Azher University, Cairo, Egypt. \\ (2) Faculty of Science, Al-Azhar University, Girls Branch, Cairo, Egypt. \\ (3) Higher Technological Institute (HTI), 6th October Branch, 6th October City, Egypt. \\ (4) National Institute of Standards, Tersa st, Giza, Egypt. \\ * Corresponding Author: lalsabaphysics@gmail.com.
}

\begin{abstract}
:
In this study $\mathrm{ZnO}$ nanoparticles have been prepared by sonochemical method (also known as sonochemitry). The aim of using this method is the simplicity of obtaining nanoparticles in small times and without using any heating to initiate the chemical reaction. Different with other traditional chemical methods, the sonochemical method is based on acoustic cavitations. The formation, growth and collapse of bubbles in the liquid were generating localized hot spots with very high temperatures of 5000-25,000 K. These temperatures are enough to initiate the chemical reaction. $\mathrm{ZnO}$ nanoparticles with sizes in the range (28- $24 \mathrm{~nm})$ are obtained by changing the time of sonication, the time period in which the suspension was exposed to Ultrasound waves. The optical band gap which obtained from UV measurements was found to be about $3.1 \mathrm{eV}$ for all samples and the characteristic band gap of $\mathrm{ZnO}$ was at around $560 \mathrm{~cm}^{-1}$.
\end{abstract}

Key words: $\mathrm{ZnO}$ nanoparticles, Sonochemical method, Sonication time, particle size, optical properties

\section{INTRODUCTION}

Zinc Oxide attracts the attention of many researchers due to its various technological applications such as ceramics, luminescent materials and gas sensors [1-3]. In addition, $\mathrm{ZnO}$ nanoparticles are used as a sunscreen due being UV- opaque and visible transparent $[4,5]$. Several methods have been used for the synthesis of ZnO-NPs. Some examples are metal-organic precursors, sol-gel, microwave assisted synthesis and sonochemical method (Sonochemistry). Sonochemistry is driven by acoustic cavitation, formation, growth, and implosive collapse of bubbles in liquids irradiated with high intensity ultrasound. Energy is transferred upon the growth and collapse of these micro-bubbles from the macro-scale acoustic wave to the micro-scale vapor inside the bubbles. Extremely high pressures (hundreds of atmospheres) and temperatures (thousands of degrees Kelvin) result from the high localization [6-10]. The sonochemical method is being used in the preparation of several nanomaterials recently. There are a few reports on the growth of $\mathrm{ZnO}$ nanostructures by sonochemical method, mostly at high temperatures [11- 13] Moreover nanorods of $\mathrm{ZnO}$ nanoparticles were successfully synthesized at room temperature following the sonochemical method [14]. In the present study, $\mathrm{ZnO}$ nanoparticles of different morphologies were prepared by sonochemical method at room temperature with different sonication time. Figure (1) shows the transient acoustic cavitation (formation, growth and implosion of bubbles) in very small period of time with a huge heat which initiates the chemical reaction without needing an external heat [15].

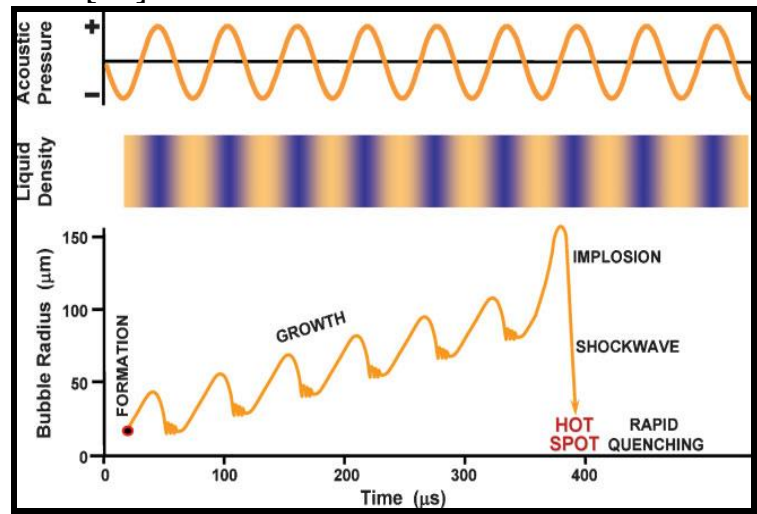

Figure (1): Formation, growth and implosion of bubbles during the sonochemical method. 


\section{EXPERIMENTAL:}

\section{- Preparation of $\mathrm{ZnO}$ nanoparticles}

$\mathrm{ZnO}$ nanoparticles were prepared by sonochemical method. Zinc acetate dihydrate $\left(\left(\begin{array}{lll}\mathrm{Zn} & \left(\mathrm{CH}_{3} \mathrm{COO}\right)_{2} . & \left.2 \mathrm{H}_{2} \mathrm{O}\right)\end{array}\right)\right.$ and sodium hydroxide $(\mathrm{NaOH})$ were used as raw materials. $0.2 \mathrm{M}$ (mole) Zinc acetate dihydrate was dissolved in $1000 \mathrm{ml}$ distilled water under stirring by using magnetic stirrer. $3 \mathrm{M}$ of aqueous solution of sodium hydroxide was added drop by drop to adjust $\mathrm{PH}$ of the solution at 13. After 10 minutes stirring, the products were sonicated at different times 2, 3 and 4 hours (using a multi-wave ultrasonic generator operating at $20 \mathrm{kHz}$ with a maximum power output of $250 \mathrm{~W}$ ) while the power was maintained at about $100 \mathrm{~W}$ for all samples. The white precipitate was filtered and washed with methanol several times to remove ionic impurities and finally dried at room temperature [14].

( $\mathrm{Zn}\left(\mathrm{CH}_{3} \mathrm{COO}\right)_{2} 2 \mathrm{H}_{2} \mathrm{O}$ decomposition to $\mathrm{ZnO}$ can be described as follows:

$$
\begin{gathered}
\mathrm{Zn}\left(\mathrm{CH}_{3} \mathrm{COO}\right)_{2} \cdot \mathrm{H}_{2} \mathrm{O}+2 \mathrm{NaOH} \rightarrow \mathrm{Zn}(\mathrm{OH})_{2}+2 \mathrm{CH}_{3} \mathrm{COONa}+2 \mathrm{H}_{2} \mathrm{O} \\
\mathrm{Zn}(\mathrm{OH})_{2}+2 \mathrm{H}_{2} \mathrm{O} \rightarrow \mathrm{Zn}(\mathrm{O})_{4}^{2+} 2 \mathrm{H}^{+} \\
\mathrm{Zn}(\mathrm{OH})_{4}^{2+} \rightarrow \mathrm{ZnO}+\mathrm{H}_{2} \mathrm{O}+2 \mathrm{OH}^{-}
\end{gathered}
$$

\section{- Structural Measurements}

X-ray diffraction measurements of the samples are recorded with Multi-purpose X-ray Diffractometer (X'Pert-MPD system) using $\mathrm{CuK} \alpha$ radiation $(\lambda=0.154056 \mathrm{~nm})$ at an $\mathrm{X}$-ray tube of Power $3050 \mathrm{~W} / 00 \mathrm{Cu}$ LFF $(40 \mathrm{kV}$, 30mA). Transmission electron microscope (TEM- JEOL Co., Made in Japan, with MaxPower of $600 \mathrm{KX}$, Max-Resolution of $0.2 \mathrm{~nm}$, Max-Energy of $120 \mathrm{KV}$ ) has been used to investigate the morphology of the $\mathrm{ZnO}$ nanoparticles.

\section{- Optical Measurements}

FT-IR measurements were performed using Fourier Transform Infrared Spectrophotometer (Shimadzu FTIR-8400 S, Japan). The spectra of samples were taken in the range of $\left(400-4000 \mathrm{~cm}^{-1}\right)$. UV-Vis Absorption measurements were carried out using double beam Spectrophotometer (Type: JASCO Corp., V-570, and Rev. 1.00) with a photometric accuracy of \pm 0.002 to \pm 0.004 absorbance.

\section{RESULTS AND DISCUSSION: \\ 1.1. Structural Measurements}

\subsubsection{XRD Measurements}

Fig.2 shows the XRD pattern of the sonochemicaly prepared $\mathrm{ZnO}$ nanoparticles at 2, 3, and 4 hours. All observed diffraction peaks are the characteristic of crystalline wurtzite hexagonal phase of $\mathrm{ZnO}$ according to (JCPDs, card no. 36-1451) [16]. In addition, weak diffraction peaks were detected at low diffraction angles (not shown) for sample sonicated for 3 hours resulting from minor alkaline residuals. Nonetheless, the sharp and intense diffraction peaks imply the high degree of crystallinity of all as prepared samples.

Interplane spacing $d_{100}$ and $d_{002}$, lattice parameters $(\mathrm{a}, \mathrm{c})$ and the unit cell volume were calculated using equations (1-3) [17], and tabulated in table (1).

$$
\begin{aligned}
& d_{h k l}=\frac{\lambda}{2 \sin \theta} \\
& \frac{1}{d^{2}}=\frac{4}{3} \frac{h^{2}+h k+k^{2}}{a^{2}}+\frac{l^{2}}{c^{2}} \\
& V=\frac{\sqrt{3} a^{2} c}{2}=0.866 a^{2} c
\end{aligned}
$$

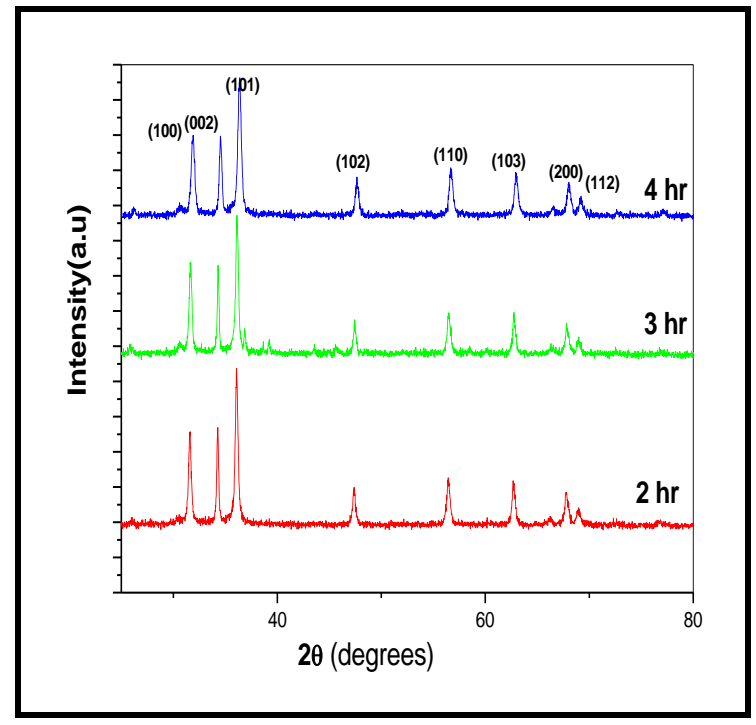

Figure (2): XRD patterns of $\mathrm{ZnO}$ nanoparticles sonicated at 2,3 and 4 hours. 
Table (1): The structural parameters of $\mathrm{ZnO}$ nanoparticles sonicated at 2,3 and 4 hours.

\begin{tabular}{|c|c|c|c|c|c|c|}
\hline \multirow{2}{*}{$\begin{array}{l}\text { Sonication } \\
\text { time }\end{array}$} & \multirow{2}{*}{ (hkl) } & \multirow{2}{*}{$\begin{array}{c}\text { Interplane } \\
\text { spacing } \\
\mathrm{d} \\
(\mathrm{nm})\end{array}$} & \multicolumn{3}{|c|}{ Lattice parameters } & \multirow{2}{*}{$\begin{array}{c}\mathrm{V} \\
(\mathrm{nm})^{3}\end{array}$} \\
\hline & & & $\begin{array}{c}\mathrm{a} \\
(\mathrm{nm})\end{array}$ & $\begin{array}{c}\mathrm{c} \\
(\mathrm{nm})\end{array}$ & $\mathrm{c} / \mathrm{a}$ & \\
\hline \multirow{2}{*}{$2 \mathrm{hr}$} & (100) & 0.28 & \multirow{2}{*}{0.33} & \multirow{2}{*}{0.52} & \multirow{2}{*}{1.6} & \multirow{2}{*}{0.049} \\
\hline & (002) & 0.26 & & & & \\
\hline \multirow{2}{*}{$3 \mathrm{hr}$} & (100) & 0.28 & \multirow{2}{*}{0.33} & \multirow{2}{*}{0.52} & \multirow{2}{*}{1.6} & \multirow{2}{*}{0.049} \\
\hline & (002) & 0.26 & & & & \\
\hline \multirow{2}{*}{$4 \mathrm{hr}$} & (100) & 0.28 & \multirow{2}{*}{0.32} & \multirow{2}{*}{0.52} & \multirow{2}{*}{1.6} & \multirow{2}{*}{0.046} \\
\hline & (002) & 0.26 & & & & \\
\hline
\end{tabular}

As shown in table (1), no noticeable change in lattice parameters for all samples which in a good agreement with that of bulk $\mathrm{ZnO}$. Therefore, we can conclude that all chosen sonication times used are appropriate in the preparation process.

The average crystallite size (D) was calculated by $\mathrm{x}$-ray diffraction line broadening using the Scherer equation:

$$
\mathrm{D}=\mathbf{0} \cdot \frac{9 \lambda}{\beta \cos \theta}
$$

Where $\lambda$ is the $\mathrm{X}$-ray wavelength $(\lambda=$ $1.5406 \AA), \theta$ is the Bragg diffraction angle and $\beta$ is the full width at half maximum $[17,18]$.

In addition, Williamson- Hall (W- $\mathrm{H}$ ) analysis using Uniform Deformation Model (UDM) $[18,20]$ can be applied to calculate crystallite size and internal strain:

$$
\beta \cos \theta=\frac{\mathrm{k} \lambda}{\mathrm{D}}+4 \varepsilon \sin \theta
$$

Where, $\varepsilon$ is the internal strain. The average crystallite size and internal strain can be obtained by plotting $4 \sin (\theta)$ versus $\cos (\theta)$ as shown in Fig. 3.
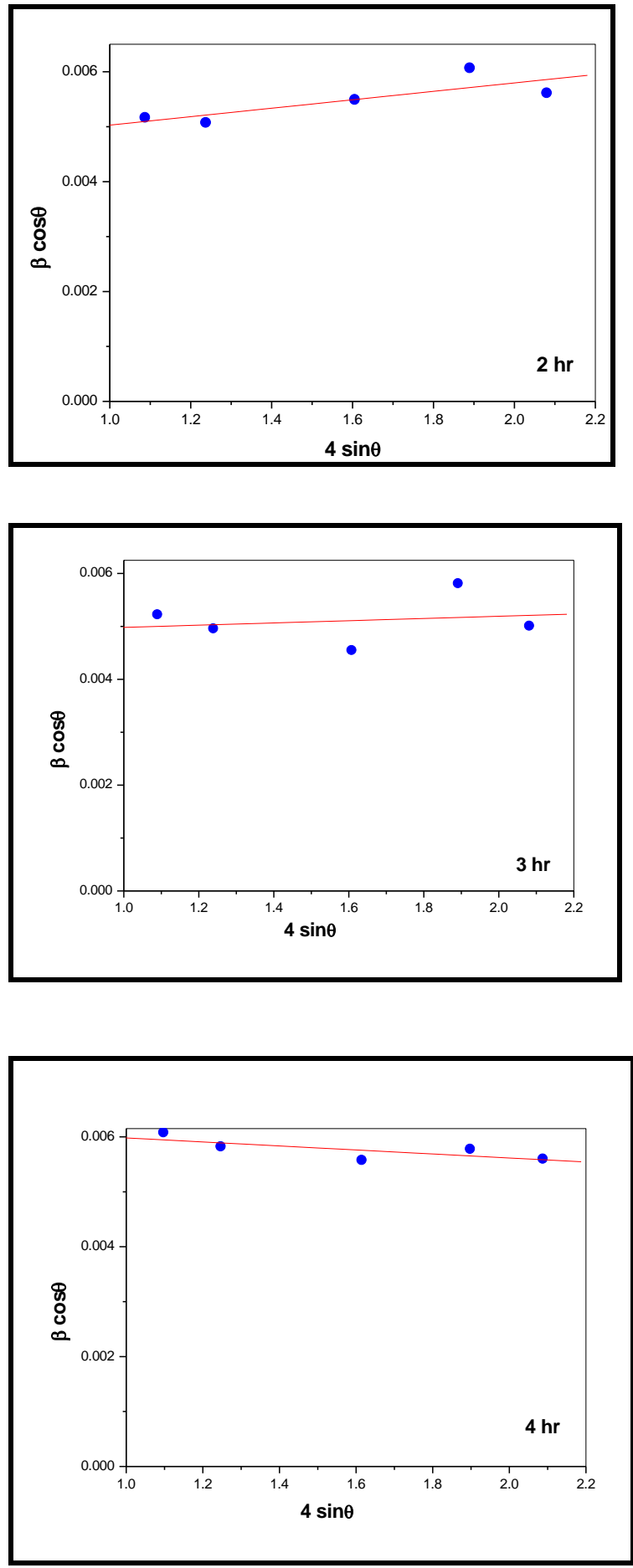

Figure (3): The W-H analysis using UDM of of ZnO nanoparticles sonicated at 2, 3 and 4 hours.

The estimated crystallite size using both Scherer equation and UDM (W-H analysis) are summarized in Table 2 . The strain values were found to be in the order of $10^{-4}$ for all samples. 
Table (2): crystallite size estimated from Scherrer equation, and $\mathrm{W}-\mathrm{H}$ method using UDM.

\begin{tabular}{|c|c|c|}
\hline $\begin{array}{c}\text { Sonication } \\
\text { time }\end{array}$ & $\begin{array}{c}\text { Particle size } \\
\text { (D) from } \\
\text { Scherer } \\
\text { equation }(\mathrm{nm})\end{array}$ & $\begin{array}{c}\text { Particle size (D) } \\
\text { from UDM } \\
\text { (nm) }\end{array}$ \\
\hline $2 \mathrm{hr}$ & 28 & 28 \\
\hline $3 \mathrm{hr}$ & 26 & 28 \\
\hline $4 \mathrm{hr}$ & 24 & 23 \\
\hline
\end{tabular}

The internal strain values may infer from another relation [21]:

$$
\varepsilon=\frac{\Delta \mathrm{d}}{\mathrm{d}_{0}} \tan \theta
$$

Where $\Delta \mathrm{d}$ is the change of interplane spacing due to strain, $d_{o}$ is the standard interplane spacing value of bulk Zinc Oxide. The value of internal strain found to be in the order of $10^{-4}$ which matches with those calculated by W.H method.

TEM images of samples sonicated at 2, 3 and 4 hours are depicted in Fig. 4 . The presence of individual particles as well as aggregated ones for all samples can be clearly observed. It is very evident that, The morphology of the particles changed from rod-like shape to hemispherical-like shape by rising sonication time. Due to the slight change in particle size values, we can decide that the change of sonication time is a highly efficacious for controlling the shape of particles rather than changing of the particles size.

\subsection{Optical Measurements}

\subsubsection{FTIR Measurements}

The identification of functional groups of different sonicated samples was performed by FTIR spectroscopy, and the typical spectra for all samples are presented in Fig. 5. The spectra of all samples were recorded in the range 400$4000 \mathrm{~cm}^{-1}$. The broad bands in the range of $3500-3420 \mathrm{~cm}^{-1}$ can be assigned to the $\mathrm{O}-\mathrm{H}$ stretching vibrations, resulting from the presence of water and hydroxyl groups on the particle surface. The assignments for all observed FTIR bands for the samples were
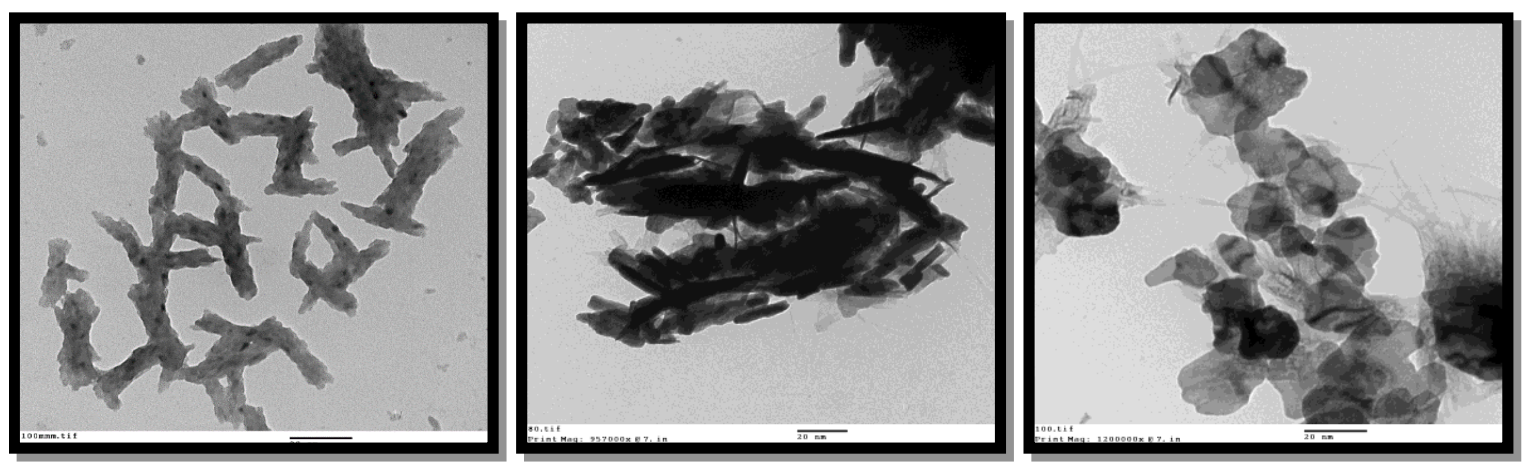

Figure (4): TEM images for samples sonicated for 2,3 and 4 hours.

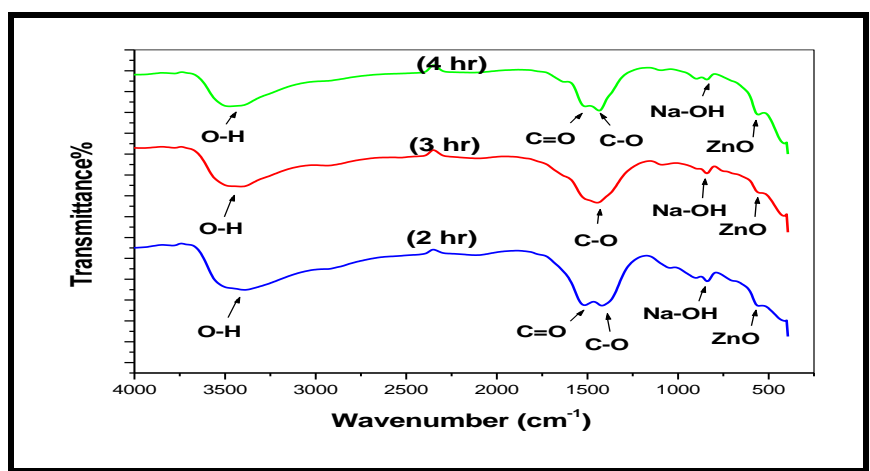

Figure (5): FTIR spectra of samples sonicated for 2,3 and 4 hours.

Table (3): Assignment for all observed FTIR bands for samples sonicated at 2, 3 and 4 hours.

\begin{tabular}{|c|c|c|c|c|c|}
\hline Position cm-1 & $3500-3430$ & $1520-1510$ & $1420-1400$ & $840-820$ & At around 560 \\
\hline Assignment & $\mathrm{O}-\mathrm{H}$ stretching & $\mathrm{C}=\mathrm{O}$ & $\mathrm{C}-\mathrm{O}$ & $\mathrm{Na}-\mathrm{OH}$ & $\mathrm{ZnO}$ \\
\hline
\end{tabular}


tabulated in Tables 3 . The bands of metal oxide generally appear in the region below $1000 \mathrm{~cm}^{-1}$ [22]. The absorption band noticed at $560 \mathrm{~cm}^{-1}$ is the typical characteristic band of $\mathrm{ZnO}$ stretching modes [23-25].

\subsubsection{UV-Visible Measurement}

The optical investigation of the samples was carried out by UV-Vis absorption spectroscopy measured at room temperature. The prepared samples characterized by dispersing the powder in distilled water. The absorption spectra for the samples are presented in Fig. 6a, where no absorption band detected in UV-Visible range. The optical band gap can determined according to Tauc's relation [26, 27]:

$$
(\alpha h v)^{\frac{1}{n}}=\mathrm{A}\left(h v-\mathrm{E}_{\mathrm{g}}\right)
$$

where $\alpha$ is the absorption coefficient, $\mathrm{h} v$ is the energy of incident photon, $\mathrm{A}$ is constant, $E_{g}$ is the optical band gap and $n$ is the power factor of the transition mode with values $0.5,2,1.5$ and 3 corresponding to allowed direct, allowed indirect, forbidden direct and forbidden indirect transitions respectively [27] . The dependence of $(\alpha h v)$ on the photon energy $h v$ was plotted for $n=0.5$. Fig. $6 \mathrm{~b}$ shows the relation between $(\alpha h v)^{2}$ versus photon energy $h v$. The optical band gap value can be determined from the intersection of extended linear portionof the curve with hv axis as seen in Fig. 5. The direct optical band gap has the value $3.1 \mathrm{eV}$ for all prepared samples which is close to that of bulk Zinc Oxide [29, 30].

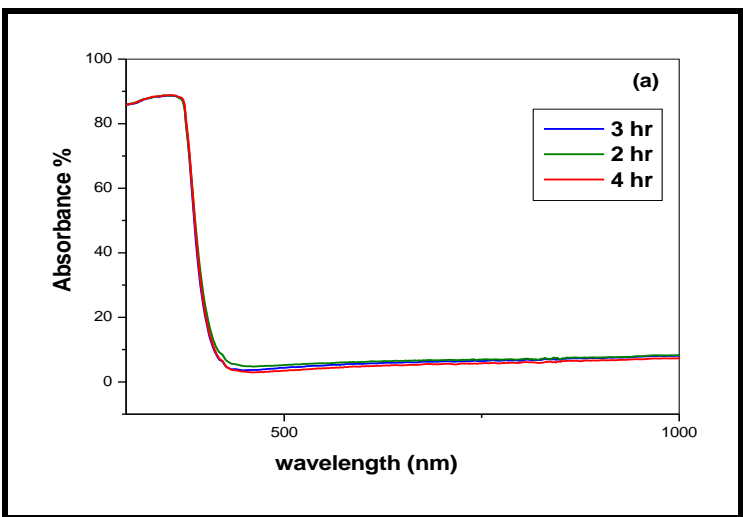

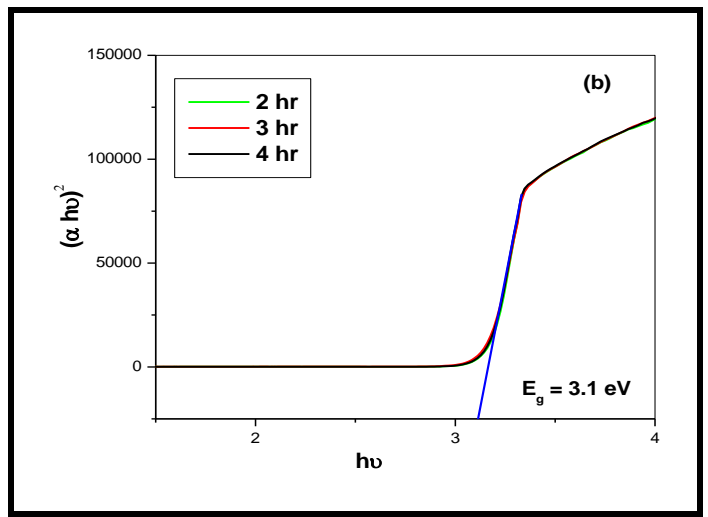

Figure 6: (a) Absorption spectra and (b) The relation between $(\alpha h v)^{2}$ versus hv for 2,3 and 4 samples.

\section{CONCLUSION:}

$\mathrm{ZnO}$ nanoparticles have been successfully synthesized by sonochemical method with different sonication times (2, 3 and 4 hours) to know the effect of sonication time on the particle size and on the value of band gap. XRD results show that, all synthesized $\mathrm{ZnO}$ nanoparticles have wurtzite hexagonal phase with lattice constants very close to that of bulk zinc oxide. No remarkable changes in particle size by altering sonication time which in consistence with that observed by TEM images, while the morphology of particles was changed from rod-like shape to hemispherical-like shape. We have applied Williamson- Hall (W$\mathrm{H})$ analysis using Uniform Deformation Model (UDM) to calculate the value of the internal strain. The internal strain calculated was having very small value $\left(10^{-4}\right)$. The FTIR characteristic $\mathrm{ZnO}$ absorption band was observed at about $560 \mathrm{~cm}^{-1}$. The band gap of all samples obtained From UV absorption measurements was found to be $3.1 \mathrm{eV}$.

\section{REFERANCES:}

[1] X. Zhao, S.C. Zhang, C. Li, B. Zheng, H. Gu, J. Mater. Synth. Process. 5, 227(1997).

[2] S. Sakohara, M. Ishida, M.A. Anderson, J. Phys. Chem. B. 102, 10169(1998).

[3] S. Hingorani, V. Pillai, P. Kumar, M.S. Muntai, D.O. Shah, Mater. Res. Bull. 28, 1303, (1993).

[4] J. M. Jassim, Y. H. Khadim, M. M. M. AlSultani, Journal of Engineering and Applied Sciences, 13, (80-88) (2018).

[5] A. L. Briseno, T. W. Holcombe, A. I. Boukai, E. C. Garnett, S. W. Shelton, J. J. M. Frechet, P. Yang, Nano Lett 10: 334 - 340, (2010). 
[6] Y. Hsiou, W. Hung, C. Wang, Atlas Journal of Materials Science, 2, (60-64), (2015).

[7] V. Musat, B. Teixeira, E. Fortunato, R.C.C. Monteiro, P. Vilarinho, Surf. Coatings Technol. 180- 181(659-662) (2004).

[8] B. Joseph, K.G. Gopchandran, P.K. Manoj, P. Koshy, V.K. Vaidyan, Bull. Mater. Sci. 22 (921-926) (1999).

[9] S. Bhatia, N. Verma, A. Mahajan, R.K. Bedi, Appl. Mech. Mater. 772 (50-54) (2015).

[10] A. Venkateswara Rao, MD. Parvez Ahmad, K. Suresh Babu and G. Narsinga Rao, Materials Chemistry and Physics 224 (79-84) (2019).

[11] X. Zhang, H. Zhao, X. Tao, Y. Zhao, Z. Zhang, Mater. Lett. 59, 1745 (2005).

[12] X.L. Hu, Y.J. Zhu, S.W. Wang, Mater. Chem. Phys. 88, 421(2004).

[13] C. A. Ubani and M. A. Ibrahim, Materials Today: Proceedings 7, (646-654), (2019).

[14] S.G. Ansari, Rizwan Wahab, Young-Soon Kim, Hyung-Kee Seo, Hyung- Shik Shin, Applied Surface Science 253, (7622-7626) (2007).

[15] Jin Ho Bang and Kenneth S. Suslick, Adv. Mater, 22, (1039-1059), (2010).

[16] JCPDS (Joint Committee on Powder Diffraction Standards) database collected via the "PCPDFWIN" software.

[17] A. Khorsand Zak, W.H. Abd. Majid, M.E. Abrishami, Ramin Yousefi, Solid State Sciences 13, (251- 256) (2011).

[18] B. D. Cullity, "Elements of x-ray diffraction", (Addison-Wesley publishing company, Inc., California, Vol. 1, 531(1956).

[19] M. Salavati- Niasari, F. Davar, M. Mazaheri, M. Shaterian, J. Magn. Magn. Mater. 320, (575-578) (2008).

[20] M. Birkholz, "Thin Film Analysis by X- ray Scattering", Wiley-VCH Verlag GmbH and Co. KGaA, Weinheim, Vol 1, 378, (2006).

[21] M. Rajendran, R.C. Pullar, A.K. Bhattacharya, D. Das, S.N. Chintalapudi, C.K. Majumdar, Journal of Magnetism and Magnetic Materials $232,(71-83)(2001)$.

[22] G. Korotcenkov, Sang Do Han, B.Cho, Valeri Tolstoy, 3 (1-2), (19-28) (2009).

[23] JR. Ferraro, "Low frequency vibrations of inorganic and co-ordination compounds", Plenum Press, New York, 309 (1971).

[24] A. Hernández, L. Maya, E. Sánchez-Mora and E. M. Sánchez, J Sol-Gel Sci Techn 42 (71-78) (2007).

[25] T. Lopez, J. Mendez, T. Zamudio, M. Villa, Mater Chem Phys, 30, (161-167), (1992).
[26] E.A. Davis, and N.F. Mott, Philosophical Magazine, Vol 22, (903-922), (1970).

[27] E.A. Davis, Mott and N.F, "Electronic processes in non-crystalline materials", Clarendon Press (Oxford and New York) 2nd ed, 590 (1979).

[28] A. N. Banerjee, K. K. Chattopadhyay, in D. Depla, S. Maheiu (Eds.), Springer- Verlag: Berlin, Heidelberg, 2008.

[29] L.I. Berger, "Semiconductor Materials", CRC Press, Boca Raton, Fla, USA, 122, 472, (1997).

[30] S. Talam, S. Rao Karumuri and N. Gunnam, ISRN Nanotechnology, Article ID 372505, 6 pages (2012).

$$
\begin{aligned}
& \text { الملخص العربي } \\
& \text { در اسة الخو اص التركيبية و الضوئية لأكسيد الزنلك } \\
& \text { النانومترى المحضر بالطريقة السونوكيميائية } \\
& \text { مصطفى عبداله عشوش1 ، اسماء عبد الغني عماره } 4 \text { ، }
\end{aligned}
$$

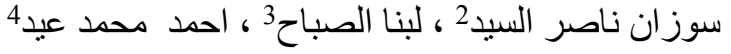

$$
\begin{aligned}
& 1 \text { كلية العلوم - جامعة الاز هر - القاهرة - مصر ،2 كلية } \\
& \text { العلوم فرع البنات - جامعة الازهر - القاهرة ، } 3 \text { ـ المعهد } \\
& \text { العالي للتكنولوجيا ــ فرع السادس من اكتوبر ـمدينة } 6
\end{aligned}
$$

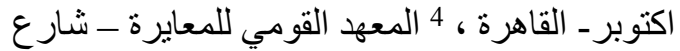

$$
\begin{aligned}
& \text { ترسا ــ الجيزة - القاهرة - الهرة }
\end{aligned}
$$

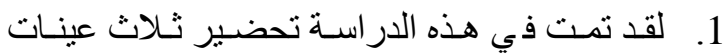

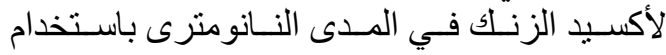

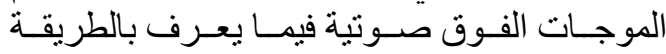

$$
\begin{aligned}
& \text { السونوكيميائية. } \\
& \text { 2. تتميز الموجات الفوق صـوتية باحداثها لقيم عاليـة }
\end{aligned}
$$

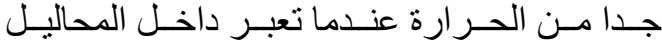

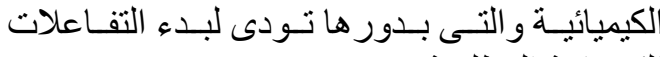

$$
\begin{aligned}
& \text { الكيميائية المطلوبة توبة. } \\
& \text { 3. قد تم تحضير ثنلاث عينات عند قيم مختلفة من زمن فئ }
\end{aligned}
$$

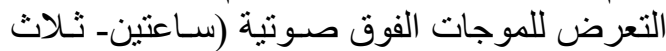

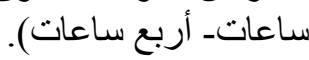

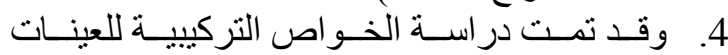

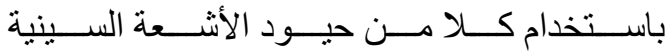

$$
\begin{aligned}
& \text { و الميكروسكوب الالكترونى. }
\end{aligned}
$$

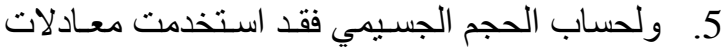

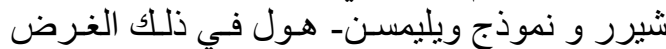

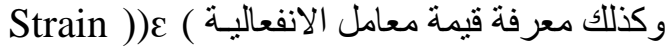

$$
\begin{aligned}
& \text {.( modulus } \\
& \text { 6. ولدر استة الخو اص الضوئية فقد اسـتخدمت كـلا مـن فئ }
\end{aligned}
$$

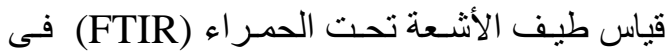




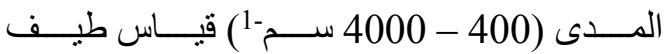

الامتصاص و الانبعاث فى المدى النانومنرى (200)

- . - 800 نانو متر ).

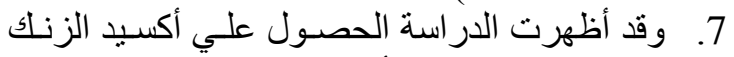

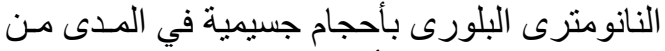

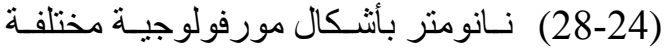

وبحاجز جهد يسـاوى 3.1 الكترون فولت لتان للعينـات

الثلاث. 